\title{
THE BRYOPHYTE DIVERSITY OF LJUBLJANA (SLOVENIA)
}

\author{
Mitja Skudnik, Aneta Sabovljević, Franc Batič \& Marko Sabovljević
}

\begin{abstract}
The authors studied the bryophyte flora of the city of Ljubljana (Slovenia), recording 104 bryophyte taxa within the inner ring-road of Ljubljana. The specimens were collected from randomly picked sampling sites during different seasons in 2011 and 2012. Interesting records include Barbula convoluta var. commutata (Jur.) Husn., Grimmia trichophylla Grev., Leptobryum pyriforme (Hedw.) Wilson, Phascum cuspidatum Hedw. and Pseudocrossidium hornschuchianum (Schultz) R. H. Zander, species last recorded in Slovenia more than 60 years ago. Some species rare and endangered in Slovenia were also recorded: Syntrichia papillosa (Willson) Jur. and Lunularia cruciata (L.) Lindb. Rhynchostegium rotundifolium (Scop. ex Brid.) Schimp., a moss red-listed Europea-wide, was recorded in the investigated area.
\end{abstract}

Key words: urban flora, mosses, liverworts, Ljubljana, Slovenia

Mitja Skudnik, Slovenian Forestry Institute, Večna pot 2, 1000 Ljubljana, Slovenia

Aneta Sabovljevic, Marko Sabovljević, Institute of Botany and Garden, Faculty of Biology, University of Belgrade, Serbia; e-mail:marko@bio.bg.ac.rs

Franc Batič, Department of Agronomy, Biotechnical Faculty, University of Ljubljana, Slovenia

\section{INTRODUCTION}

The bryophyte flora of towns forms a significant part of urban vegetation, but the available data on them are few (Ron et al. 1987; Sabovljević \& Sabovljević 2009 and references therein). Urbanization creates a spectrum of preconditions (specific microhabitats) for rich bryophyte floras (Fudali 1994, 1996, 2006; Sabovljević \& Grdović 2009). The urban bryophyte vegetation is interesting not only for its floristic composition but also for the presence of rare and significant taxa and for the vegetation relationships, and it presents material of interest from a phytogeographical point of view (Grdović et al. 2009). Urban bryophytes can be used as bioindicators for assessment of air quality, and they are accumulators of heavy metals from atmospheric deposition (Giordano et al. 2004).

Slovenia is one of Europe's bryologically richest areas, and certainly has the highest bryophyte diversity in Southeast Europe (Sabovljević et al. 2001, 2011; Sabovljević 2004). Slovenia has nearly 800 bryophyte species; the exact number varies according to the nomenclature used by various authors (Martinčič 2003; Sabovljević
\& Natcheva 2006; Ros et al. 2007; Sabovljević et al. 2008), and it changes with the addition of new bryophyte records for the country (e.g., Blockeel et al. 2009). Despite its relatively small area, Slovenia has almost all biomes of Europe due to its position and orography.

Despite ongoing bryological investigations (Martinčič 2003 and references therein), some places in Slovenia are under-recorded and others are bryologically unknown. More field research is needed.

Slovenia has towns evenly spread over its territory and relatively well preserved nature. After Finland and Sweden it is the third most forested country of Europe, with $62 \%$ of its land covered with forest (FAO \& JRC 2012). The diversity of the bryophyte flora within urban areas in Slovenia has been neglected. Apart from a few bryophyte records from towns, there has been no research addressing bryophyte diversity in any urbanized area of Slovenia.

Ljubljana is the capital and the largest city in Slovenia. It is situated in the center of the country in the Ljubljana basin between the Alps 
and the Dinaric karst region. Ljubljana is inhabited by $c$ a 280,000 people in an area of $163.8 \mathrm{~km}^{2}$ (Anonymous 2012). The city stretches over an alluvial plain dating to the Quaternary. The nearby older mountainous regions date to the Mesozoic (Triassic) or Paleozoic. Within the city there are hilly regions like those of Tivoli or Golovec. The average elevation of the city is $295 \mathrm{~m}$ a.s.1 (city center $298 \mathrm{~m}$, city castle $366 \mathrm{~m}$ ). The main watercourses in Ljubljana are the Sava, Ljubljanica, Gradaščica, Mali Graben, Iška and Išcica rivers.

Ljubljana has an oceanic climate with continental characteristics such as warm summers and moderately cold winters. Average yearly temperature is $10.1^{\circ} \mathrm{C}$. July and August are the warmest months with daily highs generally between 25 and $30^{\circ} \mathrm{C}$, and January is the coldest month with temperatures mostly oscillating around $0^{\circ} \mathrm{C}$. Annually the city experiences 90 days of frost and 11 days with temperatures above $30^{\circ} \mathrm{C}$. Precipitation is relatively evenly distributed through the seasons, although winter and spring are somewhat drier than summer and autumn. Average yearly precipitation is $1393 \mathrm{~mm}$, with 115 rainy days, making Ljubljana one of the wettest European capitals. Snow is common from December to February; on average there are 48 days with snow cover recorded each winter. The city is known for its fog, which is recorded on average 64 days per year, mostly in autumn and winter, and can be particularly persistent during temperature inversions. In summer the weather in the city is influenced by Mediterranean air currents, so the summers are sunny and warm.

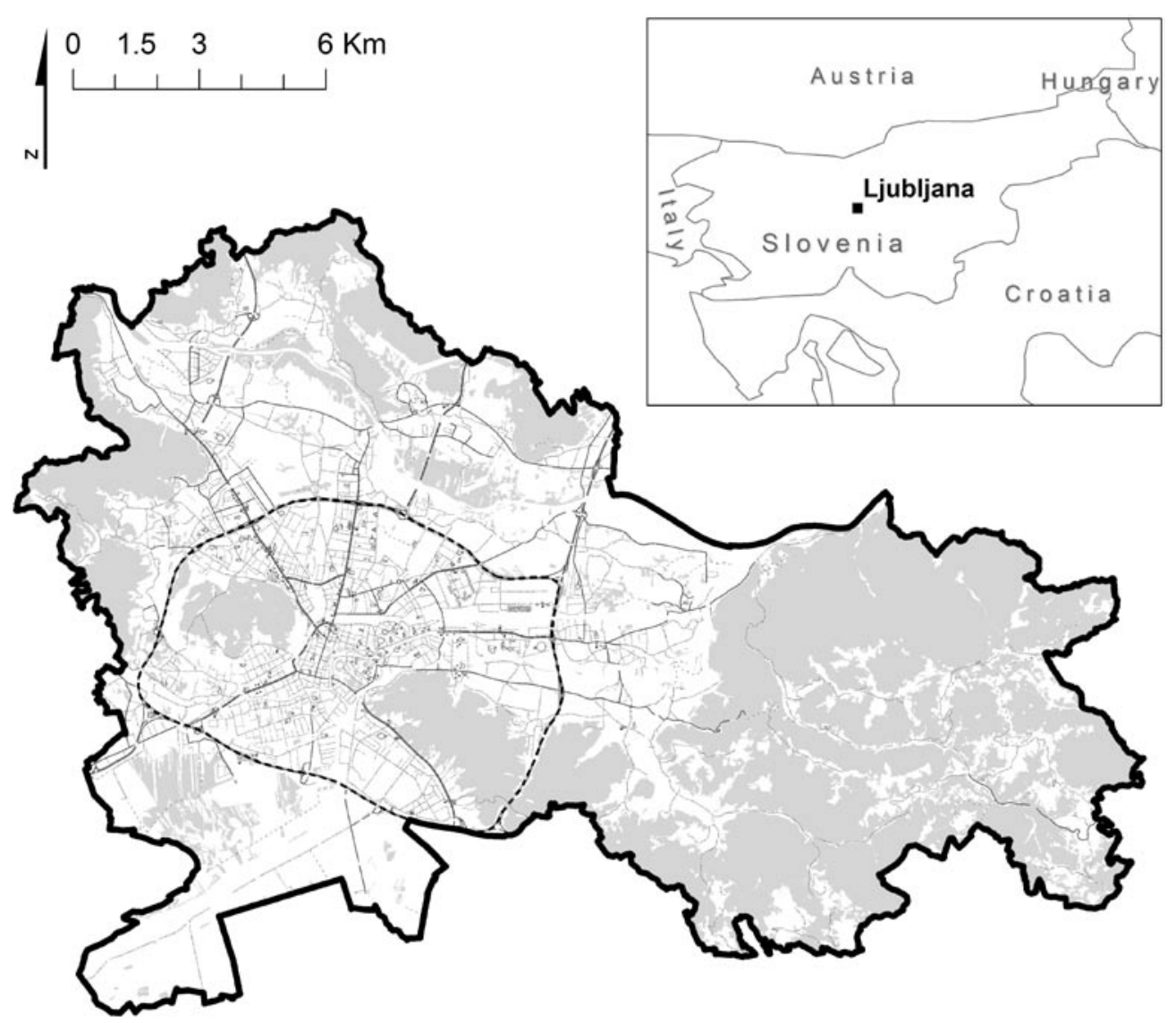

Fig. 1. Location of Ljubljana in Slovenia. Dashed line demarcates the studied area in Ljubljana. 


\section{MATERIAL AND METHODS}

An extensive bryophyte collection was made in Ljubljana city (within the ring road, Fig. 1) during winter 2011 and spring, summer and autumn 2012. Random sampling was done in different habitats and microhabitats within the urban area, including larger green areas. Nomenclature follows Sabovljevic and Natcheva (2006) for hepatics and Sabovljević et al. (2008) for mosses.

\section{RESULTS}

Within the city of Ljubljana, 104 bryophyte taxa were recorded, 90 of which $(86.54 \%)$ belong to mosses (45 acrocarpus, 45 pleurocarpus mosses) and $14(13.46 \%)$ to hepatics. They are listed below in the bryophyte catalogue. Hepatics and mosses are listed separately and alphabetically. Specimens are deposited in the Belgrade University Herbarium (BEOU) and the Slovenian Forestry Institute in Ljubljana.

\section{BRYOPHYTE CATALOGUE OF LJUBLJANA CITY}

\section{LIVERWORTS}

1. Bazzania trilobata (L.) Grey

2. Calypogeia fissa (L.) Raddi

3. Chiloscyphus polyanthos (L.) Corda

4. Cephalozia sp.

5. Conocephalum conicum (L.) Dumort.

6. Diplophyllum albicans(L.) Dumort.

7. Fossombronia sp.

8. Lophocolea bidentata (L.) Dumort.

9. Lunularia cruciata (L.) Lindb.

10. Marchantia polymorpha L. subsp. ruderalis Bischl. \& Boissel.-Dub.

11. Metzgeria furcata (L.) Dumort.

12. Pedinophyllum interruptum (Nees) Kaal.

13. Porella platyphylla (L.) Pfeiff.

14. Radula complanata (L.) Dumort.

\section{MOSSES}

15. Abietinella abietina (Hedw.) M. Fleisch.

16. Amblystegium serpens (Hedw.) Schimp.

17. Atrichum undulatum (Hedw.) P. Beauv.

18. Barbula convoluta Hedw. var. commutata (Jur.) Husn.

19. Barbula covoluta Hedw.

20. Barbula unguiculata Hedw.
21. Brachytheciastrum velutinum (Hedw.) Ignatov \& Huttunen

22. Brachythecium albicans (Hedw.) Schimp.

23. Brachythecium mildeanum (Schimp.) Schimp.

24. Brachythecium rutabulum (Hedw.) Schimp.

25. Brachythecium salebrosum (Hoffm. ex F. Weber \& D. Mohr) Schimp.

26. Bryum argenteum Hedw.

27. Bryum caespiticium Hedw.

28. Bryum capillare Hedw.

29. Bryum dichotomum Hedw.

30. Bryum moravicum Podp.

31. Calliergonella cuspidata (Hedw.) Loeske

32. Ceratodon purpureus (Hedw.) Brid.

33. Climatium dendroides (Hedw.) F. Weber \& D. Mohr

34. Cirriphyllum piliferum (Hedw.) Grout

35. Dicranella heteromalla (Hedw.) Schimp.

36. Dicranella varia (Hedw.) Schimp.

37. Dicranum scoparium Hedw.

38. Didymodon acutus (Brid.) K. Saito

39. Didymodon luridus Hornsch.

40. Didymodon rigidulus Hedw.

41. Didymodon vinealis (Brid.) R. H. Zander

42. Diphyscium foliosum (Hedw.) D. Mohr

43. Encalypta streptocarpa Hedw.

44. Encalypta vulgaris Hedw.

45. Entosthodon fascicularis (Hedw.) Mull. Hal.

46. Fissidens bryoides Hedw.

47. Fissidens dubius P. Beauv.

48. Fissidens taxifolius Hedw.

49. Fissidens viridulus (Sw. ex anon.) Wahlenb.

50. Fontinalis antipyretica Hedw.

51. Funaria hygrometrica Hedw.

52. Grimmia pulvinata (Hedw.) Sm.

53. Grimmia trichophylla Grev.

54. Herzogiella seligeri (Brid.) Z. Iwats.

55. Homalothecium sericeum (Hedw.) Schimp.

56. Hypnum cupressiforme Hedw.

57. Hypnum lacunosum (Brid.) Hoffm. ex Brid.

58. Isothecium alopecuroides (Lam. ex Dubois.) Isov.

59. Kindbergia praelonga (Hedw.) Ochyra

60. Leptobryum pyriforme (Hedw.) Wilson

61. Leskea polycarpa Hedw.

62. Leucobryum juniperinum (Brid.) Mull. Hal.

63. Mnium thomsonii Schimp.

64. Orthotrichum affine Schrad. ex Brid.

65. Orthotrichum anomalum Hedw.

66. Orthotrichum cupulatum Hoffm. ex Brid.

67. Orthotrichum diaphanum Schrad. ex Brid.

68. Orthotrichum lyellii Hook. \& Tayl.

69. Oxyrrhynchium hians (Hedw.) Loeske 
70. Oxyrrhynchium speciosum (Brid.) Warnst.

71. Phascum cuspidatum Hedw.

72. Physcomitrella patens (Hedw.) Bruch. \& Schimp.

73. Plagiomnium affine (Blandow ex Funck) T. J. Kop.

74. Plagiomnium cuspidatum (Hedw.) T. J. Kop.

75. Plagiomnium rostratum (Schrad.) T. J. Kop.

76. Plagiomnium undulatum (Hedw.) T. J. Kop.

77. Plagiothecium laetum Schimp.

78. Plagiothecium nemorale (Mitt.) A. Jaeger

79. Plagiothecium piliferum (Sw.) Schimp.

80. Platygyrium repens (Brid.) Schimp.

81. Platyhypnidium riparioides (Hedw.) Dixon

82. Pogonatum aloides (Hedw.) P. Beauv.

83. Pohlia cruda (Hedw.) Lindb.

84. Pohlia nutans (Hedw.) Lindb.

85. Polytrichastrum formosum (Hedw.) G. L. Sm.

86. Pseudocrossidium hornschuchianum (Schultz) R. H. Zander

87. Pseudoleskeella catenulata (Brid. ex Schrad.) Kindb.

88. Pseudoleskeella nervosa (Brid.) Nyholm

89. Pseudoscleropodium purum (Hedw.) M. Fleisch.

90. Rhynchostegiellatenella (Dicks.) Limpr.

91. Rhynchostegium murale (Hedw.) Schimp.

92. Rhynchostegium rotundifolium (Scop. ex Brid.) Schimp.*

93. Schistidium apocarpum compl.

94. Sphagnum squarrosum Crome

95. Syntrichia papillosa (Willson) Jur.

96. Syntrichia ruraliformis(Besch.) Dull

97. Syntrichia ruralis (Hedw.) F. Weber \& D. Mohr

98. Thuidium delicatum (Hedw.) Schimp.

99. Thuidium recognitum (Hedw.) Lindb.

100. Thuidium tamariscinum (Hedw.) Schimp.

101. Tortula lanceola R. H. Zander

102. Tortula modica R. H. Zander

103. Tortula muralis Hedw.

104. Tortula subulata Hedw.

\section{DISCUSSION AND CONCLUSIONS}

This study gives the first insight into the bryophyte flora of the city of Ljubljana. Though only the inner city zone (within the ring-road) was the subject area for this investigation, the results show that Ljubljana city has quite a rich bryophyte flora, documented with 104 taxa.

Some species were not expected in the urban area (e.g., Diphyscium foliosum), but since Ljubljana has a hilly relief and lush plantlife, well- functioning hydrological regime and relatively wet climate, and is between pre-Alpic and pre-Dinaric regions, the high number of species and interesting findings are not surprising.

Among the recorded taxa is one red-listed for Europe: Rhynchostegium rotundifolium (rare European species, Anonymous 1995). In Ljubljana it was not rare on Golovec hill in the southeastern part of the city and also on Grad hill in the central part. We collected it a few times and the moss bore sporophytes.

According to Martinčič (2003), the last time Barbula convoluta var. commutata, Grimmia trichophylla, Leptobryum pyriforme, Phascum cuspidatum and Pseudocrossidium hornschuchianum were recorded in Slovenia was more than 60 years ago.

Barbula convoluta var. commutata was recorded only in the Dinaric region, while Grimmia trichophylla was known from the Alpic and preAlpic region sixty years ago (Martinčič, 2003). We recorded the first taxon on Grad hill among rocks, and the other one three times in the central/ southeastern parts of the inner city. Both taxa are rather under-recorded in Slovenia.

Leptobryum pyriforme was known from various areas in Slovenia (not from Ljubljana), and it is an easily spreading species. The absence of a report for it in more than 60 years is rather the consequence of the lack of bryological field research. Similarly, the two terrestrial species Phascum cuspidatum and Pseudocrossidium hornschuchianum have been overlooked for a long time but were present in various parts of Ljubljana.

The epiphytic moss Syntrichia papillosa and the thalloid liverwort Lunularia cruciata are redlisted in the flora of Slovenia (Martinčič 1992).

Syntrichia papillosa is considered rare throughout Slovenia (Besednjak et al. 2008). In Ljubljana it is not rare but recorded on many trees throughout the investigated area. It is not clear whether its distribution decreased in the past as a result of air pollution, but nowadays high air humidity and relatively unpolluted air favor that population. The second half of the 20th century is generally regarded as a period of retreat and extinction of epiphytes due to increased air pollution and high exposure to $\mathrm{SO}_{2}, \mathrm{NO}_{\mathrm{x}}$ and dust 
(e.g., Fudali 2012). There are no historical data for this species in the area of investigation or in Slovenia. In Ljubljana it is now common and abundant and often bears many gemmae, easily spread by insects, snails, slugs, birds or squirrels.

Lunularia cruciata is a rare liverwort outside of its main Mediterranean-Atlantic range but recorded in many European countries, mainly in urban areas. It seems to be spreading northeastward with climate warming (e.g., Sabovljević \& Marka 2009). According to Pavletić (1955) and Düll et al. (1999) it is not known in Slovenia. In the checklist of European liverworts (Söderström et al. 2002) it is cited for Slovenia. Ros et al. (2007) cite records for Slovenia, but from before 1962. Martinčič (2007) explains that these citations are based on records by Loitlesberger (1905) in Gorica (Stračice) and the Soča River bank, areas which nowadays belong to Italy. Martinčič (2007) found herbarium samples kept in LJU, collected by F. Dolšak in Ljubljana (1920 and 1938) with the label in hortis urbis Ljubljana, subspontanea. It is not clear whether this was a natural or anthropogenic habitat, but both climate change and manmade habitats favor expansion/invasion of this species. Martinčič (2007) concluded that there is no evidence for the presence of this species in Slovenia for more than 70 years. Here we confirm the presence of $L$. cruciata in various places in Ljubljana: the Botanical Gardens, Prule, Stari trg, Murgle and Tivoli. This species is easily overlooked although easy to identify by its semilunar gemma cups, and it seems to be spreading in Ljubljana at present. It probably occurs in other area of Slovenia as well.

This contribution to the Slovene bryophyte flora points to the need for more field research and analyses even in apparently well studied or species-poor areas. The inner ring-road area of Ljubljana has a rich and interesting bryophyte flora. Such high diversity supports Isermann's (2007) statement that urban bryophyte diversity is highest where moderate environmental conditions (light, water, substrate) prevail, rather than being confined to specific habitats. Further studies will no doubt add more bryophyte species from this and other areas of Slovenia.

\section{REFERENCES}

ANONYMOUS 1995. Red Data Book of European Bryophytes. European Committee for the Conservation of Bryophytes, Trondheim.

ANONYMOUS 2012. Statistical year book 51. Statistical office of the Republic of Slovenia, Ljubljana.

BesednJAK J., MARTINČIČ A. \& JOGAN N. 2008. The bryophyte flora in the vicinity of Branik (quadrant 0148/2). Hladnikia 21: 19-28.

Blockeel T. L., BaKalin V. A., Bednarek-Ochyra H., Ochyra R., Buck W. R., ChOi S., CYKowska B., ERDAĐA., ERZBERGER P., KIRMACI M., KÜRSCHNER H., LEBOUVIER M., PAPP B., SABOVlJEVIĆ M., SABOVlJEVIĆ A., SCHRÖDER W., SingH S. M., SUN B.-Y., TOWNSEND C. C., VAŇA J.\& YAYINTA O. T. 2009. New national and regional bryophyte records, 20. J. Bryol. 31: 54-62.

Düll R.,Ganeva A., MartinčIČ A. \& PAVletić Z. 1999. Contributions to the bryoflora of former Yugoslavia and Bulgaria. IDH-Verlag Bad Münstereifel.

FAO \& JRC. 2012. Global forest land-use change 1990B2005, by E.J. LindQuist, R. D'AnNunZio, A. GERRAND, K. MacDicken, F. ACHARD, R. Beuchle, A. Brink, H.D. Eva, P. MayauX, J. San-Miguel-Ayanz \& H-J. Stibig. FAO Forestry Paper No. 169. Food and Agriculture Organization of the United Nations and European Commission Joint Research Centre. FAO, Rome.

FUDALI E. 1994. Species diversity and spatial distribution of bryophytes in urban areas - a case study of the city of Szczecin. Fragm. Florist. Geobot. 39: 563-570.

FUDALI E. 1996. Distribution of bryophytes in various urban use complexes in Szczecin. Fragm. Florist. Geobot. 41: 717-745.

FUDALI E. 2006. Influence of city on the floristical and ecological diversity of bryophytes in parks and cemeteries. Biodivers. Res. Conservation 1-2: 131-137.

FUDALI E. 2012. Recent tendencies in distribution of epiphytic bryophytes in urban areas: a Wrocław case study (southwest Poland). Polish Bot. J. 57: 231-241.

Giordano S., Sorbo S., Adamo P., Basile A., Spagnuolo V. \& COBIANCHI R. 2004. Biodiversity and trace element content of epiphytic bryophytes in urban and extraurban sites of Southern Italy. Plant Ecology 170: 1-14.

Grdović S., SABOVlJEVIĆ M. \&Vitorović G. 2009. Ecological and distributional consideration of the bryophyte vegetation of urban areas: case study on Belgrade bryophytes. Journal of Applied Biological Sciences 3: 46-52.

ISERMANN M. 2007. Diversity of bryophytes in an urban area of NW Germany. Lindbergia 32: 75-81.

LOITLESBERGER K. 1905. Zur Moosflora der österreichischen Küstenländer I. Hepaticae. Verh. Zool.-Bot. Ges. Wien 55: 475-489. 
MARTINČIČ A. 1992. The Red List of Threatened Mosses (Musci) in Slovenia. Varstvo Narave 18: 7-166 (in Slovenian with English summary).

MARTINČIČ A. 2003. Annotated check-list of the mosses of Slovenia. Hacquetia 2: 91-166.

MARTINČIČ A. 2007. Critical contributions to the bryophyte flora of Slovenia, 16-23. Hladnikia 20: 17-25.

PAVLETIĆ Z. 1955. Prodromus flore briofita Jugoslavije. JAZU, Zagreb.

Ron E., Mazimpaka V., Vincente J., Granzow W. \& DE LA CERDA J. 1987. Urban bryophytes in Spanish towns. Symposia Biologica Hungarica 35: 727-753.

Ros R. M., Mazimpaka V., Abou-Salma U., Aleffi M., Blockeelt. L., Brugues M., CanoM. J., CrosR. M., Dia M. G., Dirkse G. M., El SaAdawi W., Erdag A., Ganeva A., Golnsales-Mancebo J. M., HerrnSTADT I., KHALIL K., KÜRSChNER H., LANFrANCO E., LosAda-Lima A., Refai M. S., RodrigueZ-Nunez S., Sabovljević M., Sergio C., Shabbara H. M., SimSim M. \& SödERSTRÖM L. 2007. Hepatics and Anthocerotes of the Mediterranean, an annotated checklist. Cryptog. Bryol. 28: 351-437.

SABOVLJEVIĆ M. 2004. Comparison of the bryophyte flora of the three southern European mainlands: the Iberian, the Apennine and the Balkan peninsulas. Braun-Blanquetia 34: $21-28$.

Sabovljević M. \& GRDović S. 2009. Bryophyte Diversity
Within Urban Areas: Case Study of the City of Belgrade (Serbia). International Journal of Botany 5: 85-92.

SABOVLJEVIĆ M. \& MARKA J. 2009. The biological evidence of climate changes: a case study of liverwort Lunularia cruciata (L.) Dum. ex Lindb. in Serbia. Bot. Serbica 33: 185-187.

SABOVlJEVIĆ M \& NATCHEVA R. 2006. Check list of the liverworts and hornworts of South-eastern Europe. Phytologia Balcan 12: 169-180.

SAbovljević M. \& SABovlJević A. 2009. Biodiversity within urban areas: a case study on bryophytes of the city of Cologne (NRW, Germany). Plant Biosystems 143: 473-481.

SAbovljević M., Ganeva A., Tsakiri E. \& Stefanut S. 2001. Bryology and bryophyte protection in the southeastern Europe. Biol. Conservation 101: 73-84.

SAbovljević M., Alegro A., SAbovljević A., Marka J. \& VuJIČIĆ M. 2011. An insight into diversity of the Balkan Peninsula bryophyte flora in the European background. Revue d'Ecologie (Terre et Vie) 66: 399-413.

SAbovljević M., Natcheva R., Dihoru G., Tsakiri E., Dragićević S., ERdaG A. \& PAPP B. 2008. Check-list of the mosses of Southeast Europe. Phytologia Balcan. 14: 159-196.

SÖDERSTRÖM L., URMI E. \& VÁŇA J. 2002. Distribution of Hepaticae and Anthocerotae in Europe and Macaronesia. Lindbergia 27: 3-47. 